\title{
Rights and Citizenship in Brazil: The Challenges for Civil Society
}

\author{
Almir Pereira Júnior, Jorge Romano and Marta Antunes
}

\section{Introduction}

The electoral victory of the Brazilian Worker's Party (Partido dos Trabalhadores) in 2002 raised many expectations that conservative power relations would be shifted by a new political dynamic. To date, it is clear that democratic governance is still a long way off, and that the challenges faced by civil society are increasing and changing shape. How can Brazilian civil society organisations (CSOs) best advocate for democratic governance and citizenship in this context? What are the place and role of notions such as "participation", "power" and "rights" in their work? As activists and intellectuals address these important questions, not only in Brazil but worldwide, there is a need to revisit the way such widely used concepts are understood and applied in each situation. This was the focus of a recent action research project ${ }^{1}$ carried out by ActionAid Brasil $^{2}$ with the involvement of a broad and significant range of civil society organisations.

While the research findings (see Pereira Júnior et al. 2004) offered interesting insights into these questions, much has happened during the intervening two years, so it will be necessary here to update the original reflections in relation to new challenges. The research explored the views of civil society activists about the ways they understand and link "participation" and "rights" in their discourse and practice. The first, and perhaps most important insight was the need to add a third vital concept: that of "power", to qualify and develop the debate. Respondents largely agreed that "participation", "rights" and "power" are seen by Brazilian CSOs as joined and indivisible dimensions of the same political process of the fight for citizenship. To overcome poverty and social inequalities means, in their view, to guarantee and to expand rights for excluded sectors of society. For this to occur, it is necessary to confront the relations of power and domination that drive processes of exclusion, which is only possible if society mobilises and becomes a protagonist in the fight for citizenship. But why do Brazilian CSOs make this kind of connection?

To understand this orientation and to answer the questions posed above, we have found it helpful to begin with a review of the historical evolution of notions of citizenship and rights in Brazil. This review is followed by a look at the role of civil society organisations in constructing citizenship in recent decades. Key findings from the research are then presented, demonstrating the ways in which Brazilian CSOs understand and integrate "rights", "power" and "participation" in their work. Finally, we analyse the challenges now faced by CSOs in seeking to strengthen democratic governance and build citizenship, with a focus on the dynamics of citizen participation in government Councils. These understandings of rights and participation, from the perspective of CSOs in Brazil, are critical to the way CSOs are working to influence rights in Brazil. In large part, they see rights more than formal legal standards, but as part of a wider process of social change that will address the fundamental inequalities that formal democracy has not yet been able to alter.

\section{The long road to constructing citizenship in Brazil ${ }^{3}$}

In Brazil, the notion of citizenship is very strong. But, when speaking about the Brazilian citizen, or the English citizen, or North American, we are not talking about exactly the same thing: citizenship is a complex and historically defined phenomenon. ${ }^{4}$ "Rights", understood here as the normative political basis of citizenship, are not realised in the same way 
everywhere. Usually, however, we take for granted the Anglicised version of how rights are formulated: a process which began with the establishment of civil rights, which then opened space for political rights and eventually was translated into social rights. In a country that suffered colonisation or imperialism, the sequence of acquiring and exercising "rights" is not necessarily the same.

Brazil, at the end of the colonial period, had an economy based on monoculture and large landownership, an absolute and patrimonial State, a slave society and a largely illiterate population excluded from civil, political and social rights and with no inherent sense of nationalism. The main dynamic behind independence was negotiation between the Brazilian elite, the Portuguese crown and English royalty, as opposed to the popular uprisings common in other parts of Latin America. A relatively peaceful transition resulted in a constitutional monarchy in Brazil that guaranteed the continuity of old power structures, particularly slavery, which was only abolished near the end of the monarchy in 1888.

Political rights were the first to be consolidated. The Constitution of 1824, quite liberal for its times, granted the right to vote to all men (women and slaves did not vote) over 25 years of age and with a level of income not so high in comparison with that required in other countries. However, the system of voting reinforced the power of elites, particularly that of large landowners. The vote was largely used as a form of clientelism, that is, of forced obedience, loyalty, gratitude and respect to the local bosses. The voter was not participating as a citizen but as a dependent of the local chief.

The precariousness of political rights was also apparent in the lack of civil rights. The colonial heritage was so weighty that from independence (1822) until the end of the first republic (1930) civil rights only existed de jure. The agrarian elite ruled, and largely continues to rule, by law of the "patron". The most basic civil rights, such as the right to freedom of movement, the right to property, the right to express one's ideas and the right to organise, were completely dependent on the power of the landlord. As a result, the rule of law, exercised through the influence of large landowners and used to punish those who advocated against their interests, was not something valued or promoted by society. 'For friends, everything, for enemies, the law', is a common expression used even now that evokes this clientelism.
The emergence of a working class and labour movement introduced forces for the affirmation and promotion of rights. This occurred partly as a result of the arrival of immigrants (3 million from 1884-1920) and partly due to the urbanisation and industrialisation of big cities such as Rio de Janeiro and São Paulo. The labour movement fought for basic civil and social rights, such as the right to organise, to demonstrate, to choose work, to strike and to enact laws regulating, for example, working hours and days. However, the few civil rights that were achieved did not contribute effectively to building political citizenship.

Brazil's emergence as an independent state between 1822 and 1930 marked the first steps in the road to constructing citizenship through access to primarily political rights (translating in practice to a limited vote), civil rights (existing only in law) and social rights (incipient and very limited). This road was littered with obstacles inherited from the colonial period, including the power of large landed elites, patrimonialism, privatisation, clientelism and social hierarchies based on slavery.

Between 1930 and 1960, social rights were promoted in a limited way by the State through corporatist agreements, with the aim of demobilising incipient civil society organisations, particularly labour movements. The organisation of trade unions was co-opted and promoted by the state. Political rights, on the other hand, oscillated between severe restriction during periods of dictatorship, to expansion during periods of restored democracy. Autonomous social movements only began to progress in the mid-1950s. Their growth was due in part to a progressive faction of the Catholic Church, which, principally through liberation pedagogy (Base Education Movements) and popular cultural centres, began to support student, worker and peasant movements. In addition, the communist party took part in driving the movements. Furthermore, in rural areas, alongside the Church and communist party, Peasants Leagues began to appear with the goal of reclaiming land for landless farmers. In 1963, the Statute of the Rural Worker was declared, extending social and unionist legislation to rural areas and rural trade unionism grew rapidly. By 1964, there was a context of intense social mobilisation and a populist government that promoted "base reforms", i.e. agrarian, fiscal, banking, educational and political reforms, including granting the vote to the illiterate. 
For the first time, the popular vote began to have some weight thanks to its extension and the gradual opening of the electoral process. ${ }^{5}$

Conservative forces, with the support of the USA, were worried about this growth and mobilisation of civil society and responded with a military coup that imposed authoritarian rule for two decades. The military governments, inspired by the populist governments of the 1930s and 1940s, compensated for the limits they had imposed on civil and political rights by broadening access to social rights through state paternalism and corporative negotiations with unions, mainly in rural sectors.

In the second half of the 1970s, once the "miracle era" of economic growth had dried up, the middle classes began to vote for the opposition. In this context, there was a resurgence of workers' mobilisation, especially on the outskirts of São Paulo, through union leaders such as the current president Lula, founder of the PT (Worker's Party). In rural areas, the Catholic Church resumed its fight for land rights and the rural workers' movement again called for agrarian reform and supported major strikes by farm labourers. A popular campaign for direct elections eventually toppled the military regime in 1985 and ushered in the New Republic, although the influence of the political elite remained in every elected government up until the end of the twentieth century.

A new Constitution was approved in 1988 , also as result of popular mobilisation. In theory it is one of the most progressive normative documents in the world, having as its central focus the guarantee of citizens' rights and the expansion of political and social rights. One fundamental achievement made by CSOs was the inclusion of mechanisms of social oversight - the "Councils" - that provide an opening for direct participation of organised civil society, together with the public sector, in shaping and implementing public policies. Article 204 of the 1988 Constitution makes participation in policy making and action mandatory at all levels, through representative organisations. Again, there are gaps between theory and practice and participatory governance is still more of an ongoing battle than a consolidated practice. The elites and their allies are still in control of the major governance channels, even though some claimed to be "participatory".

Formal political democracy, however, did not solve serious economic problems such as unemployment and growing regional inequality, or social problems, such as education, health care and sanitation and simply aggravated civil rights in terms of personal security. Above all else, it did not reduce social and economic inequality. After nearly two centuries of constructing citizenship, despite some advances, the situation is still complex with many inequalities remaining. Those social rights legally granted during the dictatorship have taken precedence over political and civil rights. On the road to constructing citizenship, the strong position of the Brazilian State, dating to the colonial period, has nevertheless been influenced by patrimonialism and clientelism.

Finally, the influence of neo-liberal ideas and practices during the 1990s has further complicated the construction of citizenship. The fierce competition for resources and the central importance of the market as a self-regulating mechanism of economic and social life have created a situation in which the citizen is regarded more as a consumer than as a person with concerns about politics or collective problems. Neo-liberal ideology gradually reduces citizenship to the right to consume, transforming different kinds of rights (e.g. economic, political, social, cultural, environment) into goods. The rights-based approach has been used to package and market a more neutral version of citizenship. How can rights be re-politicised? The CSOs, particularly the social movements and more progressive nongovernmental organisations (NGOs), have a key role to play in this process.

\section{The fight for citizenship in Brazil: the role of CSOs}

Despite efforts by conservative governments and elites to concentrate power and to demobilise civil society, the social movements and NGOs have been able to consolidate their role as powerful and strategic social actors in the Brazilian political arena. Primarily after the 1980s, as the democratic process advanced, CSOs expanded and diversified in their strategies and actions. The focus of social movements and NGOs in Brazil has always revolved around three central axes: (1) combating social inequalities, (2) proposing alternative models of development and (3) fighting for democracy.

In Brazil, NGOs are a relatively new social actor in the civil society field, the majority having been created during the last 30 years. While their focus was initially to support social movements and trade 
unions, today they are seizing opportunities for a more autonomous role in politics, particularly in arenas for democratic governance and social oversight of public policies. Unlike some other countries, ${ }^{6}$ in Brazil there are strong links among progressive NGOs, social movements and labour unions. These links are built through a common political goal and strategic purpose: the fight for democracy and social justice, while maintaining the specificity and autonomy of the political identity of each actor. By the time NGOs began to affirm their political identity in the 1980s, the social movements had already built up a strong presence during the dictatorship period.

The great division is, in fact, more in relation to the growing number of new NGOs who take a neoliberal approach to rights as "consumer goods" and do not share the political values and goals of progressive NGOs and social movements. These new organisations are more linked with the market sector and evangelical faith-based entities and have inserted themselves into the haze of the so-called "third sector". Inside this diffuse term "third sector", an enormous diversity of NGOs can be found, including organisations which seek to capture state resources and privatise services. These organisations are actively engaged in the participatory arenas opened by the 1988 Constitution, but are advocating not for public interests, but for their own interests, directly linked to the interest of the elites and adopting old patrimonialist and clientelist approaches. $^{7}$

In order to affirm and to empower their political identity, the NGOs connected to the ideals of the social movements started to create networks and linkages at different levels, as, for example, REBRIP (the Brazilian Network for People's Integration) and Inter-Redes (a network of networks). The biggest and best-known effort to create synergy is the Brazilian Association of Non-Governmental Organizations (ABONG), ${ }^{8}$ to which the majority of the political NGOs, those which emerged during democratisation, are affiliated. Networking has become the main strategy for increasing the visibility and influence of CSOs within political arenas of debate and decision making.

It is important to remember that, during the 1980s and 1990s, the PT, actually leading the federal government, was closely connected to the political agenda advocated not only by the unions, but also by the social movements and progressive NGOs affiliated to ABONG. One of the PT's main critiques of the previous neo-liberal government was exactly related to the lack of effective participatory modes of governance and the alliance between the government, elites and neo-liberal segments of the "third sector", closing the space for the active voice and action of social movements, labour unions and NGOs.

With the election of Lula, a historical representative of the PT and of the leftist ideals of social change, CSOs had high expectations that the rules of the game would change and, that the time to start building real and deeper participatory governance had begun. Lula was seen as a legitimate representative of the working class and a historical ally of the social movements and NGOs. His victory was thus expected to introduce significant changes in public policy and in relations between civil society and the state. The majority of activists and intellectuals who took part in this research agreed that in the early days of the new government, the arenas for participation were being opened as never before. Social movements and the NGOs affiliated to $A B O N G$ were being recognised as legitimate actors in different spaces. Key civil society leaders were invited to assume government positions. For some, there were signs of structural change in the balance of power and that the real challenge would be "how to maintain autonomy and identity" as a CSO while working in close partnership with the new democratic government.

These were the main expectations and reflections expressed by civil society leaders during the actionresearch. But government interventions in the months that followed raised quite different challenges and questions. Before turning to these, we will share the key research findings about the ways in which Brazilian activists and intellectuals understand and use the notions of "rights", "participation" and "power". These insights, as we will see, will help us to revisit the challenges faced by CSOs in the current Brazilian context.

\section{How CSOs link rights, participation and power'}

'Rights, participation and power are articulated and inseparable dimensions of the political process to promote citizenship and to overcome social inequalities'. This quote from a representative of organised civil society captures the opinion of nearly all of the individuals and entities we heard throughout the action research process and is represented in Figure 1. 
Figure 1: Linking Participation, Power and Rights

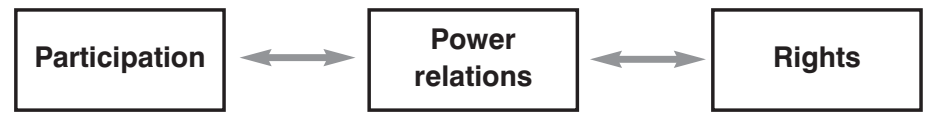

The nature of the links between rights and participation and the factors that influence these connections and synergies stem directly from the socio-political context of Brazil. CSOs have emerged through an historical process of mobilising and uniting excluded sectors of society in the struggle for democratisation, against the dictatorship and also against a long historical tradition of clientelism and elite control. The majority of those interviewed were clear about the strategic role of rights, participation and power in their agenda for action and reflection. They are seen as 'different faces of the same process to fight for citizenship': in order to overcome poverty and social inequalities, it is fundamental to affirm, guarantee and expand the rights of excluded sectors. For this to occur, it is necessary to confront relations of power and domination that drive processes of exclusion, and this in turn is only possible when society mobilises itself and becomes an active protagonist in the fight for citizenship.

To have the participation of citizens in the councils that influence politics also means to alter power, to redistribute power, socially influencing governments, so it is interesting to think in this manner, to think in a combined way: rights, participation, power. (A development NGO representative)

\subsection{Rights}

The perception of "rights" used to be linked with a normative vision of laws or public policies. By themselves, rights can sometimes be seen as inactive. But, to achieve "rights" and to make them work, the agency of social actors is needed and this is only possible through the "participation" of "powerful" people in the exercise of their citizenship. Thus, the expression of "rights" is rarely used in isolation. The "fight for rights" is a common concept and could be synonymous with "achieving citizenship". This rhetoric brings up the political dimension that connects rights to participation and power (i.e. to fight).

\subsection{Participation}

Participation was seen as the "soul of an organised civil society" and central to processes of empowerment and the fight for rights. The concept of participation has been fundamental to CSOs identity, as a democratic approach to inform their governance and social action. But they also felt it necessary to qualify their understanding of participation as different from the frequent misuse of participatory approaches, with its top-down dynamics. Participation is more than gathering people together without letting them influence the debate or taking part in decisions. There is a tension between the use of participation as a means of legitimising the power of the elites and participation as a process of constructing citizenship and changing the balance of power. It is not enough to open space to a broader "audience" or to consult people as mere informants. CSOs assert that genuine participation must open opportunities to exercise the power to decide. In this sense, it is not possible for Brazilian CSOs to talk about "participation" without talking about "power": power to raise their voices, to be heard, to make decisions.

There are long-standing and resilient barriers to effective participation rooted in gender and ethnic inequalities. These present big challenges to building an effective participatory culture in Brazil, even inside the CSOs: the main channels of political debate and decision making are still largely occupied by white men.

\subsection{Power}

Power, for Brazilian CSOs, is a multidimensional and complex concept, directly connected to processes of social injustice and impoverishment. Addressing power must take into account that: (1) it has both an internal dimension (within the organisation and its relationships with leaders and communities) and an external dimension (in relation to the state, private sector and other civil society organisations); (2) it is relational (referring directly to the dynamics and strategies of social 
Rights and Citizenship in Brazil: The Challenges for Civil Society

Table 1: Examples of How Brazilian CSOs Turn Concepts into Practice

\begin{tabular}{lll}
\hline Rights & Participation & Power \\
\hline - Constructing collective & - Motivating protaganism in the & - Participating in civil society \\
identities & community & networks \\
- Campaigns (at local, regional, & - Mobilising new leaders & - Mobilising new leaders \\
national levels) & - Community Peer Educators & - Motivating protaganism in the \\
- Participating in civil society & - Joint Effort Groups (Mutirão) & community \\
networks and fora & - Participatory management of & - Democratising information \\
- Pressure/lobbying to create & the entity and its projects & - Participating in Councils and \\
laws and policies & Participatory methodologies of & other organs of social \\
- Conducting alternative actions & project planning and evaluation & oversight \\
of public politics & Participating in civil society & - Participatory methodologies \\
- Advocating in Councils & networks & such as Reflection-Action \\
- Legal counselling & Participating in Councils and & - Participatory methodologies of \\
- Democratising information & other organs of social oversight & project planning and \\
about existing rights & Engagement in participatory & evaluation \\
- Capacity building and training & budgeting; capacity building & - Participatory management of \\
(workshops, seminars, & and training (workshops, & the entity and its projects \\
courses, etc.) & seminars, courses, etc.) & - Community Peer Educators \\
- Community Peer Educators & - Practical training (meetings, & - Income-generating projects \\
- Income-generating projects & actions, councils, etc.) & - Rotating fund for community \\
- Community radio & - Feedback of work done & development \\
- Others ... & Others ... & Capacity building and training \\
& & (workshops, seminars, \\
& & courses, etc.) \\
& & Others ...
\end{tabular}

interaction); (3) it is everywhere and is exercised in different ways; and (4) it has a strong cultural base and is subjective.

The concentration of power is seen as the main obstacle to be tackled by the CSOs in order to promote democracy and to combat poverty. On the other hand, because power is largely associated with domination, coercion and injustice, some CSOs have difficulty interpreting and acting upon the concept in its other more positive meanings such as protaganism, autonomy and the capacity to make things happen. Nonetheless, as we have seen they have a clear understanding that without power, participation is not enough to guarantee rights and citizenship.

Brazilian CSOs not only emphasise the connections among rights, participation and power, but they also see links to two other key notions which, for them, are fundamental to the way these ideas are translated into action: "Citizenship" and "Building up Subjects" (i.e. of rights).

\subsection{Citizenship}

"Citizenship" is an emblematic word in Brazil, inherited from the hard days of fighting against dictatorship in the 1970s and $1980 \mathrm{~s}^{10}$ when social movements gained strength and NGOs started to gain their political space. For activists and intellectuals, the word citizenship captures all the positive meanings of democracy, particularly the dimension of agency. Citizenship is both a goal (as the majority of the population cannot exercise it fully and have their rights denied) and a strategy (because changing power relations requires an active mindset: to see oneself and to be seen as a citizen and a subject of rights).

"Building up Subjects" is another way in which people talk about what is known in international debates as "empowerment". This notion, currently used by Brazilian CSOs, focus on the strengthening of people's self-confidence and power to present themselves as citizens (and as Subjects of rights) and as advocacy actors. But this notion also goes beyond the individual: the process of building up 
Subjects leads to collective action and to the creation of political identities to fight for rights. In this way, again the connections among rights, participation and power are evident.

It is interesting to see how Brazilian CSOs translate these notions into practical actions. Table 1 presents a synthesis of the most frequent answers given by the action-research participants when asked how they develop actions to work with each concept.

It is not a coincidence that many of the actions are repeated under different headings, principally in reference to participation and power. For the majority of Brazilian CSOs, these three concepts must be worked in an integrated and inseparable way. What might vary, depending on the context in which the action takes place, is the weight given to each of these dimensions in relation to the others in their strategies to build citizenship. It was quite impossible for Brazilian CSOs to give isolated examples of experiences of one dimension without the other. The phrase "fight for rights" is often used interchangeably to discuss experiences of mobilisation or experiences of transforming power relations.

\section{Challenges faced by Brazilian CSOs in strengthening democratic governance and building citizenship}

Despite the many advances and achievements of Brazilian CSOs during the last decades, turning theory into practice is still not easy. Some of the common obstacles to realising rights, participation and citizenship identified by participants in actionresearch are as follows:

- The culture of clientelism is still strong and causes many sectors of the population to see the conquest of their rights as "favours" bestowed by the government or politicians. This turns the poor and excluded into government hostages.

- The process of social mobilisation does not necessarily translate into an increase in political consciousness. Often mobilisation only occurs around concrete and specific needs, ending once short-term objectives are reached.

- To sustain active popular mobilisation is one of the most difficult tasks. Starting a process of participation is not so difficult; the challenge is to keep it going and with a political perspective.

- Direct participation does not change existing power relations nor bring into effect the protaganism of the community in a short period of time, it is a political process.

- Although the collective dimension is fundamental to a process of social transformation, it is also necessary to deal with the individual dimensions of change and changing personal beliefs and values is often very difficult.

- It is central to confront, without fear, the question of power, as much outside as within our own organisations.

- Rights, participation and power are complex political processes, which are very often slow and do not always achieve objectives quickly. This can cause tension due our cultural expectation of "fast results".

- We need to deepen our understanding and use of these concepts, but we are such prisoners of our everyday duties that we do not make time for a more reflexive learning process.

- Developing learning capacities requires not only the will of the CSOs, but time and resources. Many CSOs are struggling for their sustainability. Despite the supposed consensus that learning and reflection are a priority, most financing agencies do not want to invest in this part of the work.

- The communication of information and knowledge, a fundamental part of work involving rights, participation and power, is difficult when working with populations with low education levels and limited media access.

In addition to these challenges to CSOs identified in the research, there is another challenge related to the changing meanings of the key concepts in ideological debates about development and participation, see below.

\subsection{Shifting meanings in bureaucratic discourse: using our ideals against us}

Although the use in discourse and practice of notions like "rights", "participation" and "power" are rooted into the history of Brazilian CSOs, these organisations are not familiar with the international discourse and debates concerning the rights-based approach. This language has been introduced in Brazil by international organisations, particularly neo-liberal NGOs who misuse rights-based approach language to legitimise their perceptions of citizenship as market goods. This is also what 
happened when the concept of "empowerment" was introduced in Brazil, an experience worth revisiting here.

Inevitably, when social actors with diverse ideologies and practices converge around a common set of concepts, there is considerable lack of clarity and even confusion as to their real meaning. At the same time, there is a justifiable fear and mistrust among the critics of dominant development approaches who initially used these ideas and have seen them co-opted, diluted and distorted (Sen 1997). The term "empowerment" was brought to Brazil in the 1990s, used in various ways by international agencies and multilateral institutions such as the World Bank. It became stylish, and was often used within conservative policies and programmes. As a result, although "power" is an organic dimension of the identity and reflection of most Brazilian CSOs today, there remains a significant degree of prejudice and suspicion about the use of "empowerment". The irony is that much of the concept of "empowerment" was originally developed in Brazil through Paulo Freire's participatory pedagogy of reflection-action. The ideals and values proposed by Freire are still embedded and shared in most progressive sectors of civil society.

"Rights" and "participation" are now appearing more and more in the discourse and print materials of conservative social actors, as if we were all using the same language and advocating for the same issues. The semantics of CSOs have turned into the dominant discourses and practices of the mainstream, expressed through the multilateral and bilateral banks and development agencies, governments and many conservative civil society organisations; some of the same social actors responsible for processes of instigating and maintaining social inequalities and violations of citizenship. "Empowerment" in its mainstream usage often assumes the character of a gift, as something that can be granted. The focus is on access to outside resources, goods or services, disregarding organisational processes and the building of selfesteem and trust between the people. Participation is reduced to a few quick consultations at the beginning of programmes (Sen 1997). For CSO leaders, it has therefore become critical to distinguish more clearly the different ways in which Brazilian civil society understands and uses these concepts.

As the CSOs develop their critique of the misuses of development jargon, they are also trying to reaffirm the lost democratic values beneath these misapplied notions. So, the suspicion about the jargon of "empowerment" (e.g. as used by the World Bank), did not prevent them from working with the process of strengthening social actors. But they chose to use different terms to describe this, such as: development of human capabilities, changing power relations, autonomy, building up subjects and promotion of protaganism. All these signal similar processes for redistribution of power among social actors and seeking political visibility and strength for excluded people. This is more than a semantic battle. Brazilian CSOs feel that the political and democratic meanings of the concepts are being removed and exchanged for bureaucratic jargon. They thus feel a need to affirm the inner political dimensions of action, reflection and transformation by civil society.

\subsection{The new challenge: to improve spaces of participation while strengthening the autonomy and mobilising capacity of CSOs}

In recent decades, the social movements and the NGOs affiliated to ABONG have played a key role in the consolidation of the Councils as one of the most important arenas for the democratisation of governance in Brazil. The Councils are spaces of social oversight that allow direct participation of organised civil society, together with public actors in shaping and implementing public policies. As noted, the NGOs and social movements struggled to create the Councils during the 1980s and they were subsequently legalised in the 1988 Constitution. Following this success, a movement emerged to create Councils as strategic mechanisms of social oversight at all levels of public power (municipal, state and national) in relation to different areas of public policy. The general format is to create a public organ in which government and civil society representatives meet to deliberate specific policies. In some cases, these councils assume direct responsibility for the formation and monitoring of policies; in other cases they are limited to a consultative role, unable to intervene directly in decisions.

Over the years, Councils gradually multiplied throughout the country, largely on account of their potential for articulating in a concrete way the concepts of rights, participation and power. In theory, the councils are spaces that make popular participation viable in instances of decision making and the exercise of power (entering into a battle of 
forces with other social actors defending their interests) in order to realise their rights (in the form of laws and public policies). During the 1990s, CSOs tried to prepare themselves to occupy this institutional space. The work of training various social agents to intervene in these spaces took on strategic urgency. Social movements and NGOs faced the challenge of both maintaining their autonomy and at the same time engaging in the development and consolidation of democratic governance. Themes such as participatory democracy, accountability in public policies, the fight for citizenship and changing power relations had to be substantially intensified and tested.

After more than a decade of concrete experiments with Councils throughout the country and at all levels, there is no consensus within organised civil society about the potential and limitations of this space of social engagement. The concrete experience shows that the Councils, more than an end in themselves, must be seen as new arenas in the fight for citizenship. Within these arenas, the battle is difficult and complex, involving not only relationships with state representatives, but disputes among "third sector" actors.

It is important to think about councils from the point of view of expanding and refining democracy. The historical trajectory of the creation of councils is very short and the critique should revolve around revealing difficulties without forgetting the attempt by conservative governments to boycott and co-opt them. In general, the critique attempts to disqualify the mechanisms of participation. The big question is whether or not we want to expand these channels of participation and whether there is something to be revised in their functioning. We are living an historical process and we need to relate the action of various actors. The mechanisms of social oversight are micro-fields of democracy. One of the biggest problems in access to citizenship is knowing how to deal with existing mechanisms in the search for rights. (A Brazilian feminist leader)

This perspective of seeing the Councils as arenas for political dispute and not as an end in themselves in the exercise of citizenship, is becoming more and more common among CSOs, particularly due to recent experience in dealing with the new Lula government in the context of national councils.
During the first year of government, a proliferation of participatory spaces opened. Notable was the reactivation of the National Food Security Council (CONSEA) first at federal and then at state and local levels, the opening space for CSO discussion in the Pluri-Annual Plan (PPA) 2004-2007 and the creation of the Social and Economic Development Council (CDES) at the federal level. In the case of CONSEA, where CSOs were strongly mobilised at the state level, the Councils were able to incorporate some successful CSO experiences in public policies.

But despite the opening of the spaces and good results in some Councils, as in the case of CONSEA, leading Brazilian CSOs do not feel they have achieved a new balance of power with the government and with the neo-liberal organisations within these arenas for social oversight of public policies. In fact, in many key arenas, the space and the voice of the most progressive segments of civil society are diminishing, as in the recent "participatory" process used to define the PluriAnnual Plan (PPA) 2004-2007, one of the most important processes for influencing policy priorities and budgets in Brazil. At the beginning of the process, the social movements and the NGOs affiliated to ABONG were able to participate and intervene in the process. But, after several failed efforts to be recognised as key actors, particularly by government representatives, the most important Brazilians CSOs decided to formally leave this arena and instead to increase external pressure for structural changes in the participatory process.

Some of the setbacks identified in the power imbalances within these participatory arenas reinforce the critical perception that Brazilian CSOs must re-evaluate the strategic weight given to the Councils in the 1990s and to look for complementary alternatives for the exercise of social engagement and building democratic governance. The lesson learnt through concrete experience of participation in these arenas, is that the spaces are not enough in themselves, and that they cannot be seen as the only strategic channel in the fight for citizenship. It is necessary to engage not simply to legitimise the decision-making process, but to promote the quality of popular participation within these arenas. At the same time, CSOs are challenged to improve their organisational strength, to preserve their autonomy and to keep pressuring the state in traditional ways, through mobilisation and engaging with the media and public opinion. 


\section{Notes}

1. The research project 'Exploring Linkages between Rights and Participation', was carried out by ActionAid Brasil in early 2003, at the same time that the new government, led by Luíz Inácio Lula da Silva, was starting to work. The project is one of seven country studies (also including India, Indonesia, Kenya, Mexico, Nigeria and Zimbabwe) carried out in partnership with national research teams, the Institute of Development Studies, Sussex and Just Associates, Washington.

2. ActionAid Brasil, an NGO based in Rio de Janeiro since 1999, aims to support the empowerment of the most poor and marginalised groups and their organisations, in order to fight against poverty and social injustice. ActionAid Brasil is a member of ActionAid International, an organisation present in more than 40 countries.

3. This section is based on the excellent book written by José Murilo de Carvalho (2001), Cidadania no Brasil. O longo caminho. Also contributing to this reflection are the collection of essays edited by Jaime Pinsky and Carla Bassanezi Pinsky (2003).

4. Citizenship includes various dimensions or sets of rights. Traditionally, these rights are broken down into civil, political and social. In the last few years other sets of rights (economic, cultural and environmental, among others) have been added. A complete citizen would be a person capable of exercising stewardship of all these rights. An incomplete citizen would be someone deprived of some of these rights and a non-citizen would be someone denied access to any of these rights (see Carvalho 2001).

5. With the Constitution of 1946, the right to vote was

But it remains an important notion for social movements and NGOs. extended to citizens: literate men and women over 18 years old. But the illiterate remained unable to vote.

6. In other contexts, as for example in parts of Africa, the picture is not the same, due to political history and the strength of government structures. In some African countries, for example, NGOs preceded the emergence of social movements.

7. It is important to clarify that when we refer to Brazilian CSOs, we are talking about the progressive social movements and NGOs engaged into democratic approaches and not to the broader so-called "third sector".

8. The NGOs affiliated with ABONG, while a small portion of those in the country, can be identified by clear criteria. It is these NGOs that enjoy recognition by international and governmental agencies. ABONG only accepts affiliates that are autonomous from the State, churches, political parties or social movements; maintain a commitment to building a democratic society which embraces diversity and pluralism; are public in their goals and actions; have their own legal status such as non-profit civil society; and have at least two years of experience. Today ABONG has 248 affiliates.

9. This section reports on action research carried out with several dozen Brazilian CSOs between December 2002 and May 2003. Research methods included the use of a virtual questionnaire, convening three workshops, qualitative interviews and documentation of illustrative examples through key informants (see Pereira Júnior et al. 2004).

10. Nowadays, "citizenship" has begun to be (mis)used as common jargon, particularly within the so-called "third sector", depriving it of its political dimensions.

\section{References}

Carvalho, J.M. de, 2001, Cidadania no Brasil. O longo caminho, Rio de Janeiro: Civilização Brasileira

Pereira Júnior, A., Antunes, M. and Romano, J.O., 2004, Linking Rights and Participation: Brazil Country Study, Rio de Janeiro: ActionAid Brasil and Brighton: Institute of Development Studies, www.ids.ac.uk/ids/particip/research/rights/ (accessed December 2004)

1997, background paper to the Human Development Report 1997, New York: United Nations Development Programme
Pinsky, J. and Pinsky, C.B. (eds), 2003, História da Cidadania, São Paulo: Contexto

Sen, G., 1997, 'Empowerment as an approach to poverty', UNDP Working Paper 97.07, December 